\title{
CORDEL DE CONTRATOS AGRÁRIOS
}

\author{
João Aparecido dos Santos Oliveira ${ }^{1}$ \\ José Raimundo Souza de Santana ${ }^{2}$
}

Pedimos vossa atenção

Para aqui nos tolerar

Sobre contratos agrários

Iremos apresentar

Pra que a mensagem não falhe

Preste atenção nos detalhes

Da forma de explanar

Em toda legislação

Que vigorou no Brasil

Sobre contrato agrário

Antes do código civil

Entre conflitos e guerra

Nem a própria lei de terra

Sobre isso definiu

Quem primeiro regulou

Contratos por sua vez

Sendo urbano e rural

Positivando em leis

Dando resposta ao Brasil

Foi o código civil

Aprovado em dezesseis

\footnotetext{
${ }^{1}$ Graduando em Direito pela Universidade Estadual de Feira de Santana - UEFS, Turma Elizabeth Teixeira (PRONERA), militante do Movimento dos Atingidos por Barragens e colaborador do Movimento Quilombola no Estado de Pernambuco

${ }^{2}$ Graduando em Direito pela Universidade Estadual de Feira de Santana - UEFS, Turma Elizabeth Teixeira (PRONERA), militante do Movimento Luta Camponesa.
} 
Porém estabeleceu

Poucas regras específicas

Regulando as relações

Essencialmente agrícolas

Tratando proprietário

Parceiro e arrendatário

Iguais nas práticas lícitas

$\mathrm{O}$ estatuto da terra

Traz aperfeiçoamento

Suas normas editadas

Um novo regulamento

Mesmo com a limitação

É pouco a evolução

Pra contrato no momento

Mesmo com a restrição

No livre contratual

Não há modificação

Grande substancial

Parceria e arrendamento

Não há aprofundamento

Até o tempo atual

O novo código civil

Que até hoje vigorou

Locação de prédio rústico

$\mathrm{O}$ mesmo não regulou

Nem parceria rural

Deixa no regimental

Que o estatuto aprovou

No aplicável ao comodato

Também no meio rural 
O novo código copia

O que já regula o tal

Referente a empreita

A alteração foi feita

Pouco substancial

A grande inovação

Pra contrato em geral

Tanto no meio urbano

Quanto no meio rural

Seu limite e aplicação

Deve estar sob razão

Sua função social

A doutrina agrarista

Parte crítica especial

Ver então no estatuto

E em seu regimental

Com o olhar crítico e amplo

Não contribui para o campo

Ter justiça social

Já que o contrato agrário

Sua funcionalidade

Tira então do camponês

Toda possibilidade

Entre fome, peste e guerra

De ter acesso a terra

Em sua totalidade

Falar de contrato agrário

Bem caracterizado 
Podem ser consensuais

Ou bilateralizados

Onerosos ou formais

Sucessivo e ainda mais

Ser comutativizados

Esses contratos agrários

Poderão ser divididos

Em contratos nominados

Que são chamados de típicos

Ou contrato inominado

Como exemplo o comodato

Denominado atípico

O nominado ou típico

Trata de arrendamento

Englobando a parceria

Junto a esse movimento

Atípico ou inominado

Observa o comodato

Sendo esse bom exemplo

Mesmo não tendo na regra

Dessa especialidade

$\mathrm{O}$ contrato inominado

A termo de validade

Deve no seu cumprimento

Igualar arrendamento

Como obrigatoriedade

Qualquer que seja a forma

Do contrato em questão 
Cada parte vinculada

Ficará na condição

Mesmo intrinsicamente

Ou em clausula expressamente

De cumprir obrigação

Conservar e preservar

$\mathrm{O}$ recurso natural

Protegendo o mais fraco

Isso é obrigacional

Mesmo que não apareça

Exige que se obedeça

No caso contratual

Esses contratos agrários

Tem como parte integrante

De um lado o proprietário

Denominado arrendante

Em parceria rural

É denominado o tal

Como parceiro outorgante

Do outro lado portanto

Dessa mesma relação

Está o arrendatário

Que na mesma obrigação

Chama parceiro outorgado

Que é identificado

Na diferenciação

O diferencial básico

Estará relacionado 
No vantajar auferido

Pelo quadro dedicado

Referente a exploração

Do objeto em questão

O qual está vinculado

Contrato de arrendamento

Em termo determinado

Transfere uso e gozo

Do objeto contratado

Difere da parceria

Que nesse caso teria

Só o uso liberado

O pagamento em dinheiro

Valor certo e ajustado

Prever no arrendamento

Conforme determinado

Enquanto na parceria

As partes dividiriam

Tudo que foi apurado

No arrendamento o risco

Não fica pro arrendante

Logo então na parceria

É pra cada integrante

Sendo então repartido

Caso seja obtido

Prejuízo no montante

Os contratos podem ser

De forma escrita ou verbal 
Sendo tácito ou expresso

Possuem valor legal

Mas se verbal subentende

Que a lei estará presente

Em clausula obrigacional

O menor prazo é três anos

Por lei está decidido

Parceria e arrendamento

Isso deve ser cumprido

Em prazo indeterminado

Em lei está declarado

Tem que ser obedecido

Parceria e arrendamento

Se iguala nessa questão

Observar prazo mínimo

É de sua obrigação

Não se obriga a decidir

Logo o prazo definir

Em sua celebração

Prazo mínimo de três anos

Se a lavoura é temporária

De cinco se é permanente

Considera a pecuária

Sete é o mínimo normal

$\mathrm{Na}$ exploração florestal

Assim diz a lei agrária

No tocante ao que vigora

$\mathrm{O}$ preço do arrendamento 
Não pode ser ajustado

Por livre consentimento

É por lei determinado

Que não pode ser cobrado

A mais de quinze por cento

No que tange esse valor

Sua aplicabilidade

Calcula as benfeitorias

Junto a propriedade

Se intensiva a exploração

É cabível oscilação

Pela rentabilidade

Entretanto esse valor

No tipo de arrendamento

Tem-se um limite teto

Com base no fundamento

Que da parte arrendada

Não poderá ser cobrada

Maior que trinta por cento

A forma de pagamento

Conforme a norma atual

Poderá ser em dinheiro

Se assim consensual

Se por fruto decidir

Não poderá reduzir

Ao preço mínimo local

A parceria rural

Age com descumprimento 
No tocante a terra nua

Ao que diz o ordenamento

De modo a exagerar

Chegando mesmo a cobrar

Mais de cinquenta por cento

Quanto a prorrogação

Que tem por finalidade

Garantir o arrendatário

A sua seguridade

Garante ao outorgado

Se no prazo estipulado

Não conclui a atividade

A renovação consiste

Em repetir o contrato

Pode essa ser expressa

Ou então no abstrato

Renovando novamente

Com o prazo expressamente

Conforme feito no trato

Para outros uma vez

Que acabe essa vigência

O contrato se desfaz

E sem que haja imprudência

Pra que sejam bons fregueses

Minimamente em seis meses

Avisar com antecedência

No tocante a preferência

Arrendatário e parceiros 
Se iguala em condição

A frente de interesseiros

Seis meses notificados

Por trinta dias calado

Deu a vez para terceiros

Havendo alienação

Tem-se então o preferente

Sendo do arrendatário

A vontade prevalente

Mas a simples preferência

Não garante a diferença

No valor pro requerente

Sua vontade de compra

Não se iguala a condição

Logo seu tempo de uso

Não é bonificação

Sendo que quando avisado

Um prazo determinado

Exige sua decisão

O termino contratual

Veja exemplificação

Dar-se de diversas formas

Como exemplo confusão

Efeito de retomada

Ou se desapropriada

A área de execução

Abandono de cultivo

Ou prazo terminado 
Ausência de pagamento

Também por dano causado

Por distrato ou rescisão

E força maior então

Assim está declarado

Tipo de indenização

Como diz o regimento

Surge em quebra de contrato

Ou tendo investimento

Em certa benfeitoria

Que para seu dia a dia

Seja útil pro sustento

No olhar bem mais geral

Para indenização

Prever isenção de dano

Exige reparação

Frente ao contrato quebrado

O reparo é baseado

Pela última produção

Quando a indenização

Não logra efetividade

Ações que essa garante

Prever a normalidade

Podendo o outorgado

Se caso prejudicado

Reter a propriedade

Quem mais se beneficia

Conforme aqui tratado 
É o dono do imóvel

Com seu bem valorizado

Nos regimentos difusos

Sabemos que esse uso

Deixa o bem assegurado

Esse contrato permite

Com uma base legal

Que faminto e miserável

Se alimentando mal

Faça a terra concentrada

Segura, valorizada

Cumprir função social 